\title{
Content and Structure of Scientific Values
}

\section{Bilimsellik Değerlerinin İçeriği ve Yapısı*}

\author{
Kürşad Demirutku ${ }^{1}$ (), Elis Güngör ${ }^{2}$ (])
}

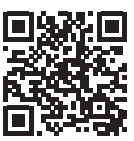

${ }^{*}$ Yazar notu: Makalenin önceki müsveddelerine verdikleri değerli görüşleri için Sinem Sonsaat Hegelheimer, Ariel Knafo-Noam ve Shalom H. Schwartz'a, ayrıca veri toplama sürecindeki yardımları için Münevver İlgün Dibek'e ve Tülin Haşlaman'a teşekkür ederiz.

'Dr. Öğr. Üyesi, TED Üniversitesi, Eğitim Fakültesi, Rehberlik ve Psikolojik Danışmanlık Anabilim Dalı, Ankara-Türkiye ${ }^{2}$ Ar. Gör., Atılım Üniversitesi, Fen-Edebiyat Fakültesi, Psikoloji Bölümü, Ankara-Türkiye

ORCID: K.D. 0000-0003-1946-4203; E.G. 0000-0003-0185-4246

\section{Corresponding author/Sorumlu yazar: Kürşad Demirutku, TED Üniversitesi, Eğitim Fakültesi, Rehberlik ve Psikolojik Danışmanlık Anabilim Dalı, Ankara-Türkiye \\ E-mail/E-posta: \\ kursad.demirutku@tedu.edu.tr}

Submitted/Başvuru: 22.09.2020

Accepted/Kabul: 07.12.2020

Published Online/Online Yayın: 09.08.2021

Citation/Atıf: Demirutku, K., Gungor, E. (2021). Psikoloji Çalışmaları - Studies in Psychology, 41(2): 459-489. https://doi.org/10.26650/SP2019-0142

\begin{abstract}
The purpose of the present research was to identify values relevant to the context of science and test their location in the motivational value circle proposed by Schwartz (1992). Based on the available scientific values literature, creativity, curiosity, skepticism, open-mindedness, rationality, objectivity, communality, integrity, and consistency values were identified as scientific values. Items were generated by the authors to measure their importance. Two studies were conducted to test five hypotheses. In Study 1 , with a student sample $\left(N=624, M_{\text {age }}\right.$ $=22$ ), results revealed that scientific values were empirically located between Self-Direction and Universalism values, and there was a sinusoidal pattern of correlations between the scientific values and the other value types. In Study 2 ( $\left.N=181, M_{\text {age }}=21.5\right)$, scientific values were observed to be positively correlated with the attitudes towards science as measured by semantic differential scales and the need for cognition scores, and negatively correlated with intolerance of uncertainty scores. The present research was the first attempt to integrate scientific values into the circular structure of values. Results were discussed as confirming the hypothesized structure of scientific values, and as providing initial support for the convergent and divergent validity of the scientific values measure. Using convenience samples with a potential self-selection bias, collecting data from Turkish university students, over-representation of women in Study 2, and low reliability coefficients for value type measures other than the scientific values were noted as methodological limitations. Attempts to replicate the results of the present research in cross-cultural studies and to investigate the relationships between the scientific values and personality measures other than the ones used in the present study to extend convergent validity are suggested as future research directions.
\end{abstract}

Keywords: Scientific values, value theory, value continuum, basic values, context-specific values 


\section{ÖZ}

Bu araştırmanın amacı bilimsel bağlamla ilişkili değerlerin tespit edilmesi ve bu değerlerin Schwartz (1992) tarafından önerilen güdüsel çemberdeki konumlarının sınanmasıdır. Bilimsellik değerleri alanyazınından hareketle yaratıcılık, merak, şüphecilik, açık fikirlilik, akılcılık, nesnellik, müştereklik, bilimsel etik ve tutarlılık değerleri bilimsellik değerleri olarak tespit edilmiştir. Bu değerlerin önemini ölçmek amacıyla yazarlar tarafından maddeler geliştirilmiştir. Beş hipotezi sınamak amacıyla iki çalışma yapılmışır. Birinci çalışmanın $\left(N=624\right.$, Ort $\left._{\text {yaş }}=22\right)$ bulguları bilimsellik değerlerinin görgül olarak Özyönelim ve Evrenselcilik değerleri arasında konumlandığını ve bilimsellik değerleri ile diğer değer tipleri arasındaki korelasyonların sinus dalgası şeklinde bir örüntü sergilediğini ortaya koymuştur. İkinci çalışmada ise $\left(N=181\right.$, Ort $\left._{\text {yas }}=21.5\right)$ bilimsellik değerlerinin semantik farklılık maddeleri ile ölçülen bilime yönelik tutumlar ve bilme ihtiyacı puanları ile pozitif, belirsizliğe tahammülsüzlük puanları ile negatif korelasyon gösterdiği gözlenmiştir. Bu araştırma bilimsellik değerlerini, değerlerin çembersel yapısıyla entegre eden ilk çalışmadır. Bulguların bilimsellik değerlerinin hipotez edilmiş olan yapısını doğruladığı ve bilimsellik değerleri ölçümünün yakınsak ve ıraksak geçerliğe sahip olduğunu desteklediği tartışılmıştır. Kendi kendini seçme yanlılığı içerebilecek uygunluk örneklemleri kullanılması, verinin Türk üniversite öğrencilerinden toplanmış olması, ikinci çalışmada kadınların erkeklerden daha fazla temsil edilmiş olması ve bilimsellik değerleri dışındaki değer tipi ölçümlerinde düşük güvenirlik katsayıları gözlenmiş olması araştırmanın yöntemsel sınırlılıkları olarak kayda geçirilmiştir. Gelecekte yapılabilecek çalışmalarda, halihazırdaki araştırma bulgularının kültürlerarası çalışmalarla tekrarlanması ve bilimsellik değerlerinin, bu çalışmada kullanılanlar dışında kalan kişilik ölçümleri ile arasındaki ilişkilerinin incelenerek yakınsak geçerlik bulgularının genişletilmesi önerilmiştir.

Anahtar Kelimeler: Bilimsellik değerleri, değer kuramı, değer çemberi, temel değerler, bağlama özgü değerler 
The problem of human values has long attracted the theoretical and empirical attention of scholars as a means to make sense of social thought and behavior (e.g., Feather, 1975; Kluckhohn, 1962; Rokeach, 1973; Schwartz, 1992). Across the many definitions of the construct, there is an empirically-supported theoretical consensus that a) values are cognitive structures organized into value systems with regard to semantic and motivational interrelationships among themselves (Pakizeh, Gebauer, \& Maio, 2007; Schwartz, 1992); b) they are ordered according to their relative importance, which is called a value priority (Rokeach, 1973); c) value priorities are distinctive of individuals, groups, and cultures (Rokeach, 1973; Schwartz, 1992, 1994); and d) these value priorities are relatively enduring, yet can change through experience (Bardi, Buchanan, Goodwin, Slabu, \& Robinson, 2014; Gouveia, Vione, Milfont, \& Fischer 2015; Sheldon, 2005; Williams, 1979). Values organize attitudes towards various attitude objects (Gold \& Robbins, 1979; Gold \& Russ, 1977; Schwartz et al., 2012; Seligman \& Katz, 1996) and guide value-expressive attitudes and behaviors when they are activated (Bardi \& Schwartz, 2003; Homer \& Kahle, 1988; Schwartz et al., 2017; Verplanken \& Holland, 2002).

The aim of the present research was to investigate how values specific to the scientific context might be integrated into Schwartz's Value Theory (SVT; 1992), Value Theory (SVT), which has become an overarching framework in the study of human values in the last three decades. SVT has a systematic approach in describing the content of human values, in explaining the rationale for their organization, and in predicting how different values or value types can be associated with outcome variables, taking the postulated organizational dynamics into account. Values of scientists have long been the interest of sociologists and psychologists (Longino, 1983; Mahoney, 1979; Rokeach, 1979; Silverman, Bishop, \& Jaffe, 1976; Tagiuri, 1965). Furthermore, teaching scientific values in education has become an important topic in curriculum development (Allchin, 1999; Corrigan \& Smith, 2015). Recent research also demonstrated that experimentally inducing importance and personal relevance for a given scientific topic increased curiosity and subsequent curiosity-satiating behaviors (Dubey, Griffiths, \& Lombrozo, 2019), thereby implying that value-based procedures might have utility in cultivating scientific values. Thus, drawing a theoretical link between scientific values and SVT, and providing empirical support for this formulation, might contribute to future psychological and educational research attempts by guiding theory-based predictions referring to the postulates of SVT. 
In the following sections, first, the theoretical basics of SVT will be introduced and the importance of context in human values research will be emphasized. Second, the previous literature on scientific values will be summarized. Finally, the hypotheses of the study will be presented together with the rationale derived from SVT as to how they might be structurally integrated into SVT and what might be expected if the measure of scientific values has convergent and divergent validity.

\section{Schwartz's Value Theory}

According to SVT, human values are cognitive representations of three universal requirements at biological, interpersonal, and intergroup levels. Ten value types are derived from these requirements and each value type is conceived as a categorization of value concepts that share the same motivational quality. Names and definitions of these value types are presented in Table 1 below (Schwartz, 2003). SVT also posits that value types are aligned as a motivational continuum around a circle. In other words, values are postulated to be ordered concerning similarities they inhere in terms of motivational goals. Therefore, adjacent domains in the circle are value types that contain values representing compatible motivational goals, whereas domains located in opposing positions contain values representing incompatible motivational goals. Thus, SVT proposes a dynamic structure for the value systems which are organized into two basic bipolar dimensions governing all compatibilities and conflicts among values. Compatible value types contain values that can be expressed in attitudes and behaviors without any conflict experienced. On the contrary, value types with incompatible motivational underpinnings can result in conflict in their pursuit. Figure 1 below depicts these structural interrelationships as proposed by SVT (Schwartz, 1996).

Table 1.Value Types and Their Definitions in the Schwartz Value Theory

\begin{tabular}{|c|c|}
\hline Value Type & Definition \\
\hline Power & Social status and prestige, control over people and resources. \\
\hline Achievement & Personal success through demonstrating competence according to social standards. \\
\hline Hedonism & Pleasure and sensuous gratification for oneself. \\
\hline Stimulation & Excitement, novelty, and change in life. \\
\hline Self-Direction & Independent thought and action-choosing, creating, exploring. \\
\hline Universalism & $\begin{array}{l}\text { Understanding, appreciation, tolerance and protection for the welfare of all people and } \\
\text { for nature. }\end{array}$ \\
\hline Benevolence & Preservation and enhancement of people with whom one is in frequent personal contact. \\
\hline Tradition & $\begin{array}{l}\text { Respect, commitment and acceptance of the customs and ideas that traditional culture or } \\
\text { religion provide the self. }\end{array}$ \\
\hline Conformity & $\begin{array}{l}\text { Restraint of action, inclinations, and impulses likely to upset or harm others and violate } \\
\text { social expectations or norms. }\end{array}$ \\
\hline Security & Safety, harmony, and stability of society, of relationships, and of self. \\
\hline
\end{tabular}

Note. Adapted from Schwartz (2003). 


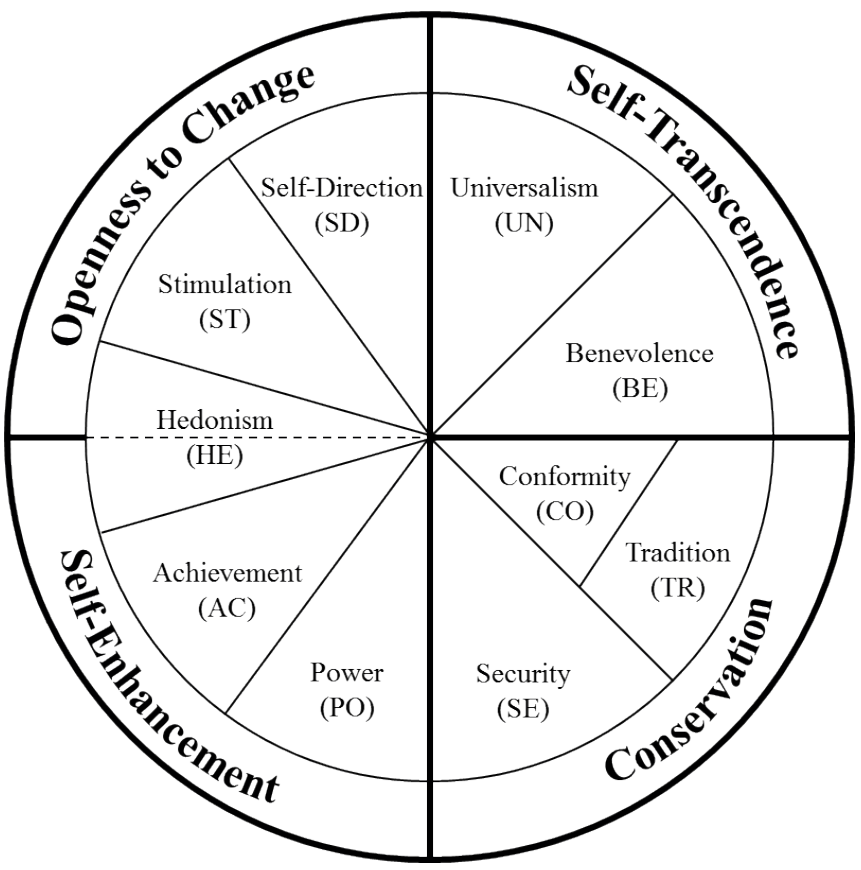

Figure 1. Motivational value circle (adapted from Schwartz, 1996)

Schwartz (1992) postulated that the relationships of all value types to a given out-come variable can be systematically predicted following the structural dynamics of the value circle. Accordingly, once motivationally the most relevant value type is theoretically identified as a correlate of a given outcome variable, the highest correlation can be expected for this value type, and the magnitude of correlations can be expected to decrease in order of distance in both directions around the circle. This requires that the distribution of correlations between value types and the outcome variable in question would reveal a sinusoidal pattern as one moves around the value circle.

This postulate was demonstrated to hold true in various studies. For instance, Schwartz (1996) hypothesized that, since Power values represented the motivational goal of dominance over people and resources, the importance attached to this value type would have the highest negative correlation with a cooperative behavioral choice on a resource allocation task. On the contrary, the importance of Benevolence values was expected to have the highest positive correlation with the same choice because this value type emphasized caring for the welfare of people that the person is in frequent contact with. Finally, the magnitude of correlations was expected to decrease monotonically 
as one moved away from the Power domain to the Benevolence domain or vice versa. Correlation analyses confirmed the hypothesized sinusoidal pattern. To sum up, SVT links the whole value system to the outcome variable on a theoretical basis rather than focusing on single values, thereby providing a holistic framework for understanding the motivational underpinnings of thought and action.

SVT highlighted the motivational goals that basic values represent, and its predictive power over various outcome variables relied on the theoretical analyses that the theory provided for linking these goals to outcome variables in different contexts. Schwartz (1992) argued that such abstract conceptualization and measurement of basic values would be instrumental in understanding the universals in the value content and structure. However, he also emphasized the context-specific conceptualizations of values for context-specific predictions in social thought and behavior. In support of this emphasis, there is evidence that a) different values might be associated with different contexts (Sagie \& Elizur, 1996), b) value priorities can dynamically rearrange across contexts (Daniel, Schiefer, \& Knafo, 2012; Daniel et al., 2012), c) values instantiated in a typical rather than an atypical context guide action better (Maio, Hahn, Frost, \& Cheung, 2009), and d) given one's stance on a social issue, specific values can become the most important guiding principles, and this reprioritization is associated with the relevant attitudes stronger than the general value priority (Seligman \& Katz, 1996). Thus, evidence suggested that context matters for which values will be utilized to guide social thought and behavior.

In agreement with the latter approach, context-specific organization of values has also been utilized both for categorization purposes and in explaining attitudes and behaviors relevant to these contexts. Family values (e.g., Toyokawa \& Toyokawa, 2013; Wakefield, Kalinauskaite, \& Hopkins, 2016), marital values (e.g., Farber, 1957; Ripley, Worthington, Bromley, \& Kemper, 2005), work values (e.g., Leuty \& Hansen, 2011), religious values (e.g., Ciarrochi \& Heaven, 2012; Huuskes, Ciarrochi, \& Heaven, 2013), and moral values (e.g., Schwartz, 2007; Yalçındağ, 2015; Yalçındağ, Özkan, \& Çoymak, 2018) are some conventional examples of such groupings.

Some studies have attempted to integrate such groupings into SVT. As an example, the meaning of work and work values (e.g., Arieli, Sagiv, \& Roccas, 2019; Ros, Schwartz, \& Surkiss, 1999) and social representations of moral values (Schwartz, 2007) 
were investigated in several studies. Given the theoretical strengths of SVT mentioned above, such studies have scientific utility in generating specific predictions based on why and how these value types might have related to cognitive, affective, and behavioral outcome variables specific to the context in question. The present research was designed to extend this line of research to the values specific to the context of science, which will be turn to in the following section.

\section{Scientific Values}

In the present study, the so-called scientific values were integrated into the motivational continuum as proposed by SVT. Scientific values have been the concern of scholars as a means to understand and evaluate the collective scientific pursuit (Mahoney, 1979). There is an agreement on the definition of scientific values that they should be differentiated from the values which surround the scientific context, and the term should be restricted to the guiding principles for scientific thought and action per se. Whereas the former type is referred to as contextual values (Longino, 1983) or cultural values (Allchin, 1999) which might affect the practice of the scientists as guiding principles of the society in which the scientists live, the latter term is reserved for guiding principles that the scientists adopt in shaping their thought processes and governing their scientific production. Longino (1983) coined the term constitutive values to refer to these values which "are the source of the rules determining what constitutes acceptable scientific practice or scientific method" (p. 8; italics added). Allchin (1999) labeled such values as epistemic values, which "promote the ultimate goal of reliable knowledge" (p. 3). Finally, Mahoney (1979) defined these values as ideals prescribing "how scientists should behave" (p. 350). To sum up, scientific values can be defined as the conceptions of the desirable means and ends which serve as guiding principles in scientific thinking and scientific production.

Past research on scientific values mostly targeted the institution of science and scientists. Tagiuri (1965) reported that the value orientations of scientists and managers were not as different as expected. Similarly, Rokeach (1979) demonstrated that there is an agreement between the scientists themselves, graduate students, and non-scientists in their perception of the value priorities which guide the institution of science. By contrast, Silverman et al. (1976) reported that graduate students in psychology were mostly different than those of a national comparison group in terms of value priorities. In addition, despite the high levels of convergence between the graduate students majoring in 
different subfields of psychology, these subfields could be grouped together with respect to slight differences in value priorities. Finally, in a national sample of mid- and early-career scientists, Anderson, Ronning, De Vries, and Martinson (2010) studied adherence to norms and counternorms of science. The results of their mail survey revealed minor differences among scientists from different disciplines. Overall, the above-mentioned studies attempted to describe the value priorities of scientists by consulting different theoretical and measurement traditions as well as comparing the value priorities of scientists with those of colleagues from other fields or with non-scientists.

There are also studies which utilized SVT to understand the value priorities of scientists. For one, Knafo and Sagiv (2004) proposed that different occupations either select individuals with certain value priorities to meet the requirements of these occupations, or individuals become socialized with work experience in those occupations to internalize the suitable value priorities. Data was collected from a diverse sample of employees in 32 different occupations. Analyses revealed that investigative-artistic occupations such as artists and scientists were characterized by a higher emphasis on Self-Direction and a lower emphasis on Tradition values. Specifically, scientists in their sample prioritized Benevolence, Self-Direction, and Universalism values, whereas Power, Stimulation, and Tradition values were observed to be the least important values. In a recent study, English, Antes, Baldwin, and DuBois (2018) conceptualized scientific values as work values in the science context. First, they developed items that they believed covered the intrinsic, extrinsic, and social aspects of scientific work values. Borrowing from the format developed by Schwartz et al. (2012), they used one-sentence person portrayals describing the importance of different goals for a scientist. Then, they measured the importance of each value by asking their scientist respondents to judge the similarity of the portrayed person in each item to themselves. Exploratory factor analyses revealed that values specific to scientific work could be grouped into eight factors: autonomy, research ethics, social impact, income, collaboration, innovation and growth, conserving relationships, and job security. They also demonstrated convergent and divergent validity of the subscales using the correlations between the subscale scores with different value type scores in refined SVT (Schwartz et al., 2012).

\section{The Present Research}

The present research diverged from the English et al. (2018) study in two ways. First, generic items were developed which could hopefully measure scientific values not specific to the scientific work. The items represented scientific values in an abstract rat- 
her than a concrete manner, as English et al. (2018) did. Such generic items might be used in future research in student populations as well as in scientist and non-scientist adult populations for theoretical and applied purposes. Second, the theoretical purpose was to test whether context-specific groupings such as scientific values could be integrated into SVT with respect to predicted motivational underpinnings. English et al. (2018) demonstrated well the structure of scientific values as composed of different aspects of the scientific work; however, they did not test theory-based locations in the value circle for each item or dimension. The present study was designed as an attempt to establish such a link between SVT and scientific values. Therefore, the present research has the potential to complement the findings of English et al. (2018).

In the present research, firstly, the content of scientific values was identified by relying on previous psychological, sociological, and educational literature on the topic. (Anderson et al., 2010; Corrigan, 2015; Corrigan \& Smith; 2015; Mahoney, 1979; Rokeach, 1979). The nine scientific value concepts were sampled are as follows: creativity, curiosity, skepticism, consistency, objectivity, rationality, open-mindedness, communality, and integrity. Secondly, items were generated which hopefully might prove useful in measuring the so-called scientific value type. Since creativity and curiosity value concepts were already represented in previous value measures (Schwartz et al., 2003; 2012), items were written only for the newly-sampled seven values. As a result, the scientific values scale used in the present study contained a total of nine value items. As for the communality and integrity values of science, items were written with a wording suitable to being used in diverse populations. The value concept of communality was represented as the transmission of knowledge, and honesty and occupational ethics were central in generating a value item for the value concept of integrity.

In writing items, the 40-item Portrait Values Questionnaire (PVQ40; Schwartz, 2003 ) format was used. Since the present research was conducted in the Turkish context, the aim in choosing this strategy stemmed from the fact that value concepts of open-mindedness, skepticism, and objectivity had low word frequency norms in the Turkish language (one, two, and three per million words, respectively; Göz, 2003). Previous research showed that word frequency is associated with meaningfulness (Klare, 1968; Paivio, Yuille, \& Madigan, 1968), and the meaningfulness of a value concept is positively associated with its perceived importance (Gardner, Reynolds, \& Beinarovics, 1969). Given these facts, the objective was to pre-empt a possible confounding in value 
ratings due to word frequency by using two-sentence portrayals. PVQ40-style value items contain two sentences, wherein the first sentence emphasizes the importance of the abstract value and the second sentence provides an exemplar to further explain it. Thus, it was hoped that respondents could have a better comprehension of the items. The scientific value concepts and items developed to measure these values are presented in Table 2 below. Finally, hypotheses were generated about where scientific values might be located in the value circle taking the motivational qualities of these values into account, and how the scientific value type scores might be associated with other values type scores adopting the sinusoidal pattern postulate of SVT and with a sample of individual difference variables if convergent and divergent validity could be demonstrated.

To start with, creativity and curiosity values were found to be located in the Self-Direction domain in past research (Schwartz, 1992; Schwartz et al., 2003), which represents the need for independence of thought and action. This is consistent with the fact that scientific thinking is fueled by a need for explanation, such that scientific questions are deemed explicable, answerable within the limits of human comprehension, and having a single true answer among many (Liquin, Metz, \& Lombrozo, 2020). In addition, scientific thinking involved in the generation of ideas, evaluation of theories, and interpretation of data, both for the scientific work of the self and one's colleagues, require critical thinking skills and freedom. Thus, it was reasoned that value concepts with direct reference to the independence of thought might exhibit closeness to the Self-Direction value type and would be dispersed away from it relatively with respect to nuances each value concept inhered. Specifically, it was expected that the values of skepticism, consistency, objectivity, and rationality would be aligned with the Self-direction values in addition to curiosity and creativity values.

Scientific pursuit is not an endeavor of fulfilling the scientific curiosity of the scientist per se. Scientists share their scientific inquiry initially with other scientists and then with third parties such as policy makers, field specialists, and the non-scientific community through various means. This requires a motivation to attend to the welfare of not only the in-group members but also the wider society. In addition, scientists are expected to be open to criticism of their work and to have a readiness for novel and challenging ideas by other scientists. These tendencies are represented by the Universalism values in SVT. Therefore, the values of open-mindedness, communality, and integrity 
Table 2. Scientific Value Concepts and the Corresponding Items in Turkish and English

\begin{tabular}{|c|c|}
\hline Scientific Value Concept & Turkish Original \\
\hline $\mathrm{SC} 1$ & $\begin{array}{l}\text { Yeni fikirler bulmak ve yaratıcı } \\
\text { olmak onun için önemlidir. İşleri }\end{array}$ \\
\hline Yaratıcılık / Creativity* & $\begin{array}{c}\text { kendine özgü yollarla yapmaktan } \\
\text { hoşlanır. }\end{array}$ \\
\hline $\begin{array}{l}\mathrm{SC} 2 \\
\text { Şüphecilik/Skepticism }\end{array}$ & $\begin{array}{c}\text { Şüpheci olmak onun için } \\
\text { önemlidir. Herhangi bir yönde } \\
\text { ikna oluncaya kadar sorgulamaya } \\
\text { ve alternatif açıklamalar aramaya } \\
\text { devam eder. }\end{array}$ \\
\hline $\begin{array}{l}\text { SC3 } \\
\text { Tutarlılık / Consistency }\end{array}$ & $\begin{array}{c}\text { Tutarlılık onun için önemlidir. } \\
\text { Düşünceleri arasında çelişki } \\
\text { olmamasını ister. }\end{array}$ \\
\hline $\begin{array}{l}\mathrm{SC} 4 \\
\text { Nesnellik / Objectivity }\end{array}$ & $\begin{array}{c}\text { Nesnellik onun için önemlidir. } \\
\text { Kanaatlerini taraf tutmadan } \\
\text { oluşturur. }\end{array}$ \\
\hline $\begin{array}{l}\text { SC5 } \\
\text { Merak/Curiosity* }\end{array}$ & $\begin{array}{l}\text { Her şeyle ilgili olmanın önemli } \\
\text { olduğunu düşünür. Meraklı } \\
\text { olmaktan ve her türlü şeyi } \\
\text { anlamaya çalışmaktan hoşlanır. }\end{array}$ \\
\hline $\begin{array}{l}\text { SC6 } \\
\text { Akılculık / Rationality }\end{array}$ & $\begin{array}{c}\text { Akılcı olmak onun için önemlidir. } \\
\text { İnsanları, fikirleri veya olayları } \\
\text { mevcut bilgileri kullanarak } \\
\text { mantıksal bir çerçevede } \\
\text { değerlendirir. }\end{array}$ \\
\hline
\end{tabular}

SC7
Müştereklik / Communality

SC8

Açı fikirlilik/

Open-mindedness

SC9

Bilimsel etik / Integrity
Bilginin aktarılması onun için önemlidir. Bildiklerini herkesin ortak kullanımına sunmak ister.

Açık fikirlilik onun için önemlidir. Genel kabul gören fikirlerden farklı veya zıt fikirleri de anlamak için çaba gösterir. Dürüstlük onun için önemlidir. Meslek ahlâkına uygun davranmak ister.
English Translation

"Thinking up new ideas and being creative is important to him/her. He/She likes to do things in his/ her own original way" (Schwartz, 2003, p. 294).

Being skeptical is important for him/her. He/She continues questioning and searching for alternative explanations until he/she is convinced in any direction.

Consistency is important for him/her. He/She wants to have no contradiction between his/her thoughts.

Objectivity is important for him/her. He/She forms his convictions impartially.

"He/She thinks it is important to be interested in things. He/She likes to be curious and try to understand all sorts of things" (Schwartz, 2003, p. 294).

Being rational is important for him/her. He/She evaluates people, ideas, and events within the framework of existing knowledge and logic.

Transmission of knowledge is important for him/ her. $\mathrm{He} / \mathrm{She}$ wants to present what he/she knows for everyone's common use.

Open-mindedness is important for him/her. He/ She puts effort into understanding ideas which are different from or opposed to those generally accepted.

Honesty is important for him/her. He/She wants to behave in accordance with occupational ethics.

Note. Items with an asterisk are the Self-Direction value items in the original PVQ40 scale (Schwartz, 2003), which were adapted to Turkish by Demirutku \& Sümer (2010), and classified as scientific values in the present study. Items without an asterisk were originally written in Turkish and then translated into English by the authors for presentational purposes.

were expected to be aligned closely with the Universalism value type.

If the reasoning stated above holds true, depending on the motivational nuances that each value concept inheres, one should observe scientific value concepts to be aligned in order between the Self-Direction and Universalism values as a continuum. Based on these arguments specific to single value concepts, the following hypothesis was proposed: 
H1: Scientific values will be located as a continuum between the Self-Direction and Universalism domains in the value circle.

Having generated the hypothetical location of the proposed scientific values, it was focused on the convergent and divergent validity of the nine-item scale. Borrowing from the postulate of the sinusoidal pattern of relationships (Schwartz, 1996), it was expected that scientific values will have the highest positive correlation with the Self-Direction and Universalism values. Independence of scientific thought might be motivationally incompatible with the importance of respect for traditional and religious modes of thinking and behaving that serve to conserve the historically-inherited status quo (Schwartz, 1992). Recent research revealed that as compared to factual beliefs which pertain to the domain of science, religious beliefs were characterized by the appeal of mystery rather than a need for explanation (Liquin et al., 2020), and were cognitively associated with the concept of believing rather than thinking (Heiphetz, Landers, \& Van Leeuwen, 2018). Therefore, it was expected that the scientific values would have the highest negative correlation with Tradition values. Similarly, the tendency for the common good in scientific production and its relation to Universalism values is in a motivational conflict with dominance over people and resources, which is represented by the Power values in SVT. Thus, it was expected that the importance of Power values was also negatively correlated with the extent of scientific matters. Following the rationale detailed above, the following hypothesis was proposed to test the convergent and divergent validity:

H2: Scientific values will have a sinusoidal pattern of correlations with other value type scores, wherein the positive peaks will be observed for Self-Direction and Universalism values, and the negative peaks will be marked for Tradition and Power values.

In addition to investigating a possible differential correlation pattern between scientific values and the other value types as an attempt to demonstrate convergent and divergent validity, the present research also aimed to examine whether scientific values might be associated with outcome variables with a potential to demonstrate convergent validity. Three variables were identified to serve this goal. The first one is attitudes towards science. Past theory and research have consistently pointed out that values as more abstract conceptions of the desirable are associated with attitudes (Gold \& Robbins, 1979; Gold \& Russ, 1977; Homer \& Kahle, 1988; Rokeach, 1973). In the scientific context, it is reasonable to expect that higher importance attached to scientific values might be as- 
sociated with more positive attitudes towards science. Therefore, the following hypothesis was proposed:

H3: Scientific values will be positively correlated with attitudes towards science.

The second variable which was identified as a potential correlate of scientific values is the need for cognition. Need for cognition is defined as the "tendency to engage in and enjoy thinking" (Cacioppo \& Petty, 1982, p. 116) as a means "to structure relevant situations in meaningful, integrated ways ... to understand and make reasonable the experiential world" (Cohen, Stotland, \& Wolfe, 1955; p. 291). It is a motivational/dispositional variable which has been demonstrated as an antecedent of effortful message elaboration that results in persuasion through the central route (Petty \& Cacioppo, 1986). Since scientific values were in part conceptualized as involving such desirable goals of independent thinking as being skeptical, rational, consistent, and creative in order to fulfill curiosity, it was argued that they are compatible with a personality orientation toward engaging in effortful thinking. Therefore the following hypothesis was proposed:

H4: Scientific values will be positively correlated with the need for cognition.

The final variable that was identified to be potentially associated with scientific values is intolerance of ambiguity. It is defined as a "tendency of an individual to consider it unacceptable that a negative event may occur" and to "find many aspects of life intolerable given that it is filled with uncertainty and ambiguity" (Buhr \& Dugas, 2002, p. 932). Intolerance of ambiguity was consistently found to be correlated with the experience of worry above and beyond other anxiety-related symptoms (Buhr \& Dugas, 2006; Dugas, Gosselin, \& Ladouceur, 2001) and the need for cognitive closure (Berenbaum, Bredemeier, \& Thompson, 2008), a tendency which is characterized by a desire for predictability, preference for order and structure, discomfort with ambiguity, decisiveness, and closed-mindedness (Webster \& Kruglanski, 1994). The structure of the need for closure construct suggests that individuals who emphasize being skeptical and open-minded can accentuate uncertainty at least up until they can arrive at a consistent and satisfactory explanation of the reality, which might require that they are more tolerant to uncertainty. Past research also revealed that Self-Direction values are negatively associated with worries about the self and close acquaintances (Schwartz, Sagiv, \& Boehnke, 2000). In a similar vein, scientific values, as motivationally compatible values 
with the Self-Direction values, thus can also be expected to be negatively correlated with intolerance of uncertainty. Following from this reasoning, it was proposed:

H5: Scientific values will be negatively correlated with intolerance of uncertainty.

Two studies were conducted in order to test the proposed hypotheses. Hypotheses 1 and 2 were tested in Study 1, and hypotheses 3-5 were tested in Study 2.

\section{Study 1}

\section{METHOD}

\section{Participants}

A convenience sample of 624 students from 32 universities and 64 departments $(1 \leq$ $n \leq 79$ ) which are located in 15 different cities in Turkey voluntarily participated in the study. Of these participants, 314 (50.3\%) were women, while 289 (46.3\%) were men, and 21 participants $(3.4 \%)$ did not report their gender. The age of the participants ranged from 18 to 35, with a mean and standard deviation of 22.0 and 2.2, respectively.

Two meta-analytic studies were located in the literature on the associations between values and dispositional variables, which revealed small-to-large (Saroglou, Delpierre, \& Dernelle, 2004) or medium-to-large (Parks-Leduc, Feldman, \& Bardi, 2015) average effect sizes. Thus, a medium effect size was expected to be observed for the correlations ( $r=.30$; Cohen, 1988) in the present study. Using the statistical tables provided in Algina and Olejnik (2003), the minimum sample size required to estimate the population parameter with $95 \%$ confidence within the range of .15 to .45 was determined to be 143 . Although this is the minimum sample size to detect medium-sized effects in correlation analyses, the data were collected from a large group of individuals so that the structural analyses of values via multidimensional scaling could hopefully reveal a reliable pattern.

\section{Measures}

Value Measure. Value priorities were measured using the Turkish version (Demirutku \& Sümer, 2010) of the 40-item Portrait Values Questionnaire (PVQ40; Schwartz et al., 2003). Each PVQ40 item presents a two-sentence portrayal of a hypothetical person. Participants then assess the similarity of each portrait to themselves on a 6-point scale ranging from 6 ("very much like me") to 1 ("not like me at all") as originally ordered on the form. The importance of values is inferred from the magnitude of these similarity 
judgments. In the present study, Cronbach's $\alpha$ coefficients for the 10 value types were observed to be between .43 (Stimulation) and .73 (Achievement). Seven newly-developed scientific value items were randomly placed among the PVQ40 items. Cronbach's alpha for the scientific values scale with all nine items was .69.

Demographic Questions. In order to measure the general characteristics of the sample, participants were asked to report their age, gender, the name of their university, and majors.

\section{Procedure}

The data were collected in May 2017 after obtaining ethical approval from the institutional review board of Atilim University. The research assistants approached potential participants on various campus locations and asked for their voluntary participation in the study. Students who agreed to participate signed the informed consent form. Then, they filled out the questionnaires on the spot. Upon completion, the research assistants answered the participants' questions if required and thanked them for their participation.

\section{Data Analysis}

Hypothesis 1 was tested by using the smallest space analysis (Guttman, 1968), which is the nonmetric version of multidimensional scaling. Pearson correlation coefficients were computed between the scientific value scores and the other value type scores to test $H 2$.

\section{RESULTS AND DISCUSSION}

Prior to analyses, the data were prepared for convenient use in required statistical tests. First of all, the average rating of the 47 PVQ items (MRAT) was computed for each respondent to be used as a control variable to partial out scale use bias in individual responses (Schwartz, 1992). Secondly, 11 value type scores, including the scientific values as a separate type, were computed by averaging the relevant items. Scientific value type scale scores were computed by using seven newly-developed items and the two Self-Direction items from PVQ40 together. Therefore, the Self-Direction value type was represented with the remaining two items. Thirdly, individual items, as well as the value type scores, were centered around the MRAT. Finally, Pearson correlation matrices were produced at each level by using the centered data and were subjected to the smallest space analysis (Guttman, 1968) as conventionally used in research on SVT (Schwartz, 1992; Schwartz et al., 2003). The structure of scientific values was tested 
twice, both at the item level and at the value type level, so that possible measurement errors in item-level analysis can be averaged across items in the value type level, which might reveal a more precise structure.

The spatial representation of the structural model is presented in Figure 2. As for the item level, which is presented in panel (a) of Figure 2 below, it is possible to observe that scientific value items display a continuum between the Self-Direction and Universalism values. The coefficient of alienation for this configuration was $.24, R^{2}=.74$. As for the value type level, which is presented in panel (b) of Figure 2 below, scientific value type was located between Self-Direction and Universalism value types, as expected. Coefficient of alienation for this configuration was $.13, R^{2}=.93$. As is conventional in SVT research, coefficients of alienation closer to zero indicate a good fit of model to data, to the extent that the hypothesized motivational continuum is observed (cf. Schwartz, 1992). Therefore, it was concluded that $H 1$ was confirmed. 


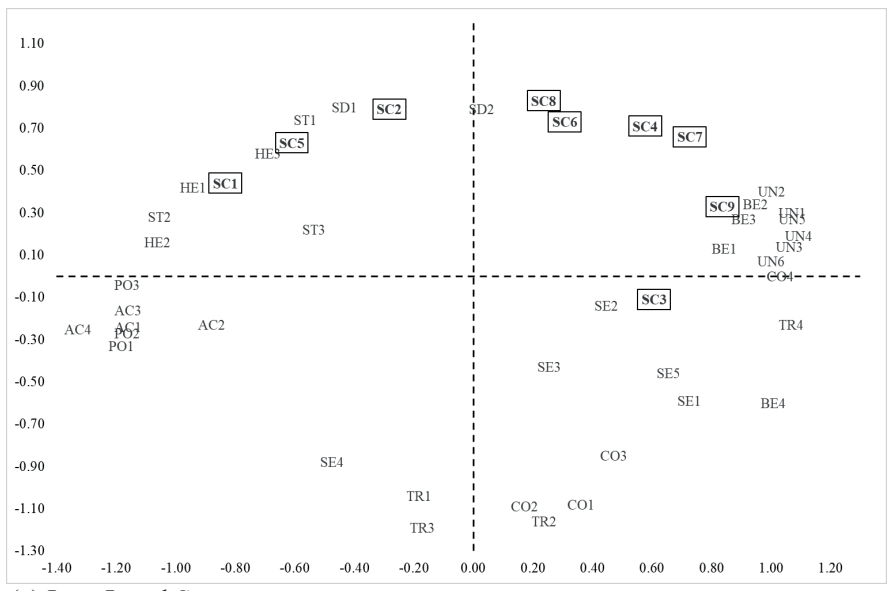

(a) Item Level Structure

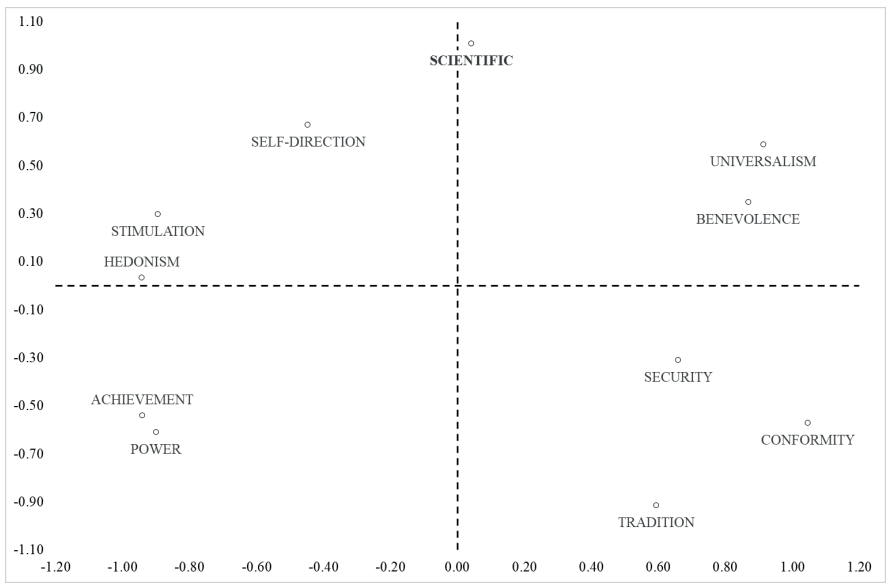

(b) Value-Type Level Structure

Figure 2. Empirical structure of scientific values

In order to test whether scientific values with gradually-changing motivational underpinnings in a continuum can be consistently grouped as a whole, the nine scientific value items were subjected to confirmatory factor analysis in LISREL 8.80 (Jöreskog \& Sörbom, 2006) by using the uncentered scores as instructed in Schwartz (2016). A single factor solution revealed a good fit of model to the data, $\chi^{2}(27, n=617)=65.465$, $p<$ $.001, \chi^{2} / \mathrm{df}=2.42$, AGFI $=0.96, \mathrm{CFI}=0.96$, TLI $=0.95, \mathrm{RMSEA}=0.05$. Thus, it is possible to conclude that the scientific value items can consistently be grouped together. 
Table 3. Correlations between Scientific Values and Other Value Types

\begin{tabular}{lcc}
\hline Value Type & Study $\mathbf{1}(N=\mathbf{5 7 8})$ & Study $\mathbf{2}(N=\mathbf{1 7 0})$ \\
\hline Power & $-.23^{* * * *}$ & $-.26^{* * *}$ \\
Achievement & $-.20^{* * *}$ & $-.23^{* * *}$ \\
Hedonism & $-.18^{* * *}$ & $-.26^{* * *}$ \\
Stimulation & -.04 & -.05 \\
Self-Direction & $.21^{* * *}$ & $.18^{* *}$ \\
Universalism & $.17^{* * *}$ & $.24^{* * *}$ \\
Benevolence & $-.11^{* *}$ & -.03 \\
Tradition & $-.35^{* * *}$ & $-.25^{* * *}$ \\
Conformity & $-.21^{* * *}$ & $-.27^{* * *}$ \\
Security & $-.13^{* * *}$ & $-.14^{*}$ \\
\hline
\end{tabular}
${ }^{*} p<.05, "{ }^{\prime \prime} p<.01, " * p<<.001$.

In order to test $H 2$, two original Self-Direction items were used, together with the seven newly-developed scientific value items, thereby obtaining a scale with nine items to compose scientific values scores. Pearson correlations between the scores of scientific value type and the other value types were computed using centered scores. Inspection of the results presented in Table 3 revealed that, as expected, the highest positive correlation was observed between scientific values and Self-Direction values $r(576)=$ $.21, p<.001$, one-tailed, which was followed by the positive correlation between the scientific values and Universalism values, $r(576)=.17, p<.001$, one-tailed . Furthermore, the highest negative correlation was observed between scientific values and Tradition values $r(576)=-.35, p<.001$, one-tailed, which was followed by the negative correlation between scientific values and Power values, $r(576)=-.23, p<.001$, one-tailed. In Figure 3, presented below, the remaining correlations showed a pattern of decrement in magnitude in both directions as the value types were farther away. To conclude, a sinusoidal pattern of correlations was observed, and thus $H 2$ was confirmed. Lastly, additional analyses revealed that age and scientific values were not correlated, nor were there gender differences in the scientific value type scores. 


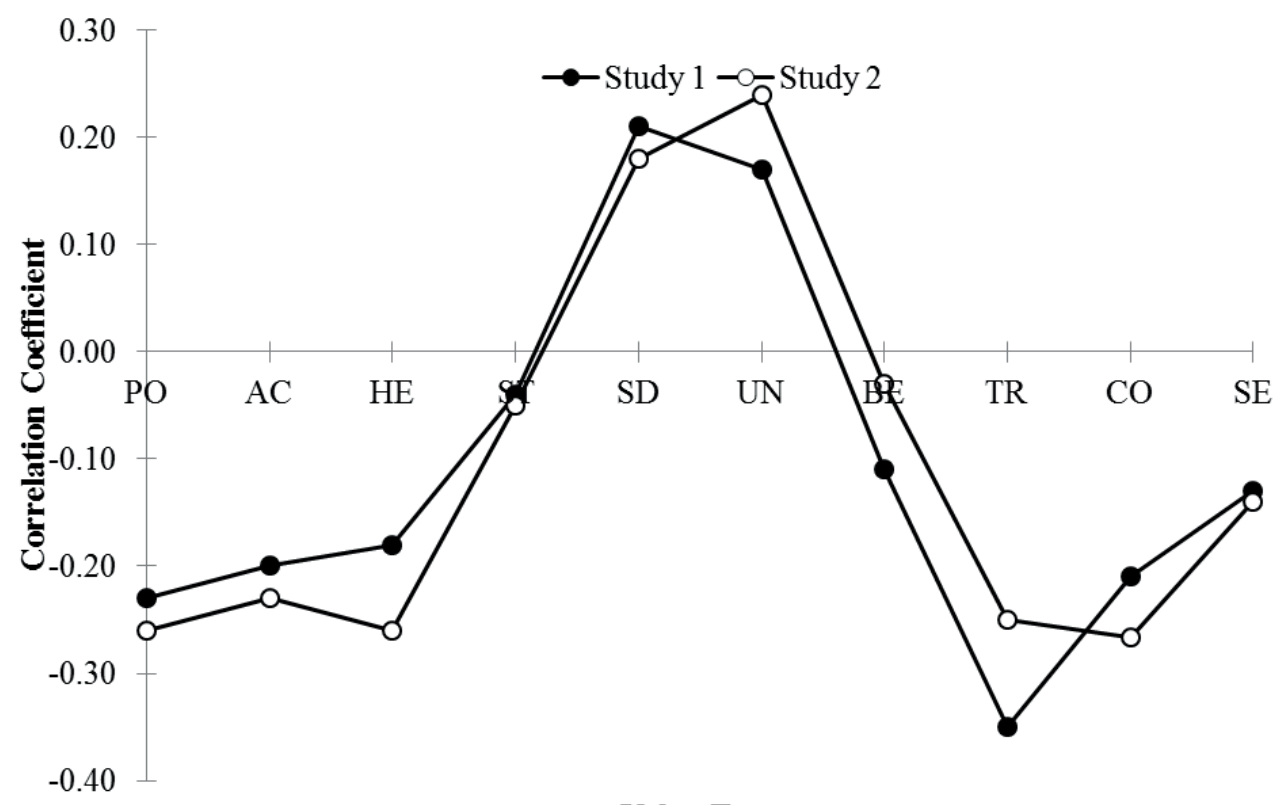

Value Type

Figure 3. Pattern of correlations between scientific values and other value types

All in all, it was obtained initial support for the structure of scientific values as indicated by relatively low coefficients of alienation yielded by the smallest space analyses. In addition, the pattern of correlations among the value types stated that there is convergent and divergent validity for the scientific value measure in a predictable fashion. Further elaboration on the empirical structure will be presented in the General Discussion section.

\section{Study 2}

\section{METHOD}

\section{Participants}

A convenience sample of 181 students from the faculty of education at a private university participated in the study for the partial fulfillment of their course requirements. Of the participants, 163 (90.1\%) were women, while 17 (9.4\%) of them were men, and one participant $(0.6 \%)$ did not report their gender. The age of the participants ranged from 19 to 42, with a mean and standard deviation of 21.5 and 2.04, respectively. As for the distribution of majors, $52.7 \%$ of the students were enrolled in the Guidance and Psy- 
chological Counselling department, $42.3 \%$ in the English Language Teaching department, and the remaining 3\% were from different departments. The criteria used in Study 1 for determining the sample size to detect medium-sized effects in correlational analyses were adopted in Study 2 as well.

\section{Measure}

Value Measure. In order to assess value priorities, the same value measure used in the first study was also used in the second study. Cronbach's $\alpha$ coefficient for the nine-item scientific value measure was observed to be .72 .

Scientific Attitudes Scale. Ten semantic differential scales (Osgood \& Suci, 1955) with seven-point bipolar intervals were administered to assess scientific attitudes. The definition of science was presented to the participants on the questionnaire, and they were asked to report their subjective judgments on semantic differential scales with balanced poles (dull-exciting, partial-impartial, shallow-deep, exact-inexact, accurate-inaccurate, valuable-worthless, pleasant-unpleasant, harmful-beneficial, right-wrong, and good-bad). Attitude scores were computed by averaging the responses to the scales. Higher scores indicated higher positive attitudes toward science (Cronbach's $\alpha=.78$ ).

The Need for Cognition Scale. The original need for cognition scale, which consists of 34 items, was developed by Cacioppo and Petty (1982) to assess individuals' tendency to think and enjoy thinking. In the present study, the short form with 18 items was used (Cacioppo, Petty, \& Feng Kao, 1984) since a Turkish-adapted version was available (Gülgöz \& Sadowski, 1995). Items are rated on a 5-point Likert type scale ("1 = not at all characteristic of me," " 5 = entirely characteristic of me"). The needs for cognition scores were computed by averaging the responses to the items. Higher scores indicated an increased demand for cognition tendency (Cronbach's $\alpha=.85$ ).

Intolerance of Uncertainty Scale. The original version of the scale was developed by Buhr and Dugas (2002). The scale was composed of 27 items and measures negative beliefs and reactions to uncertainty. Items are rated on a 5-point Likert type scale (" $1=$ not at all characteristic of me," " 5 = entirely characteristic of me"). The scale was adapted into Turkish by Sarı and Dağ (2009). Intolerance of uncertainty scores were computed by averaging the responses to the items. Higher scores indicated higher intolerance of uncertainty (Cronbach's $\alpha=.93$ ). 
Demographic Questions. Participants were asked to report their age, gender, and majors.

\section{Procedure}

The data were collected in October 2017 after obtaining ethical approval from the institutional review board of TED University (Approval decision date September 7th, 2017, No. 2017/71). The questionnaire was administered to students during in-class hours. All students participated in the study voluntarily. Signing the informed consent form, they filled out the questionnaires on the spot. The scales were always presented in the same order in the questionnaire. Upon completion, the participants' questions were answered and they were thanked for their participation.

\section{Data Analysis}

Hypotheses 3-5 were tested by computing Pearson correlation coefficients. Therefore, all following hypotheses conducted using the same analysis.

\section{RESULTS AND DISCUSSION}

First, Pearson correlations between scientific values and the other value types were computed using centered scores. Inspection of Table 3 above revealed that the sizes of the correlations were comparable to those observed in the first study. In addition, the same sinusoidal pattern of correlations was also obtained in Study 2 when Figure 3 above was inspected. The highest positive correlation was observed between scientific values and Universalism values $r(168)=.24, p<.001$, one-tailed, which was followed by the positive correlation between the scientific values and Self-Direction values, $r(168)=$ $.18, p<.01$, one-tailed. Furthermore, negative correlations were observed between scientific values and Power values, $r(168)=-.26, p<.001$, one-tailed, as well as scientific values and Tradition values $r(168)=-.25, p<.001$, one-tailed. The remaining correlations showed a pattern of relative decrement in magnitude in both directions as the value types were farther away. Therefore, further support for $H 2$ was obtained.

Means, standard deviations, and correlations among the variables of Study 2 are presented in Table 4. In line with $H 3$, scientific values were positively, yet marginally, correlated with scientific attitudes, $r(157)=.13, p=.053$, one-tailed In addition, a positive correlation was observed between scientific values and need for cognition, $r(145)=.44$, $p<.001$, one-tailed, thereby supporting H4. Finally, there was a negative correlation 
between scientific values and intolerance of uncertainty, $r(147)=-.15, p<.05$, one-tailed. Therefore, $H 5$ was also confirmed. All in all, both the pattern of correlations among value types and between scientific values and the criterion variables were in the expected directions. Thus, there is support for the convergent and divergent validity of the scientific value measure.

Table 4. Descriptive Statistics of and Correlations among the Variables of Study 2

\begin{tabular}{lcccccc}
\hline & $\boldsymbol{M}$ & $\boldsymbol{S D}$ & $\mathbf{1}$ & $\mathbf{2}$ & $\mathbf{3}$ & $\mathbf{4}$ \\
\hline 1. Scientific Values & 5.13 & 0.52 & $(.72)$ & $.13^{\dagger}$ & $.44^{* * *}$ & $-.15^{*}$ \\
2. Scientific Attitudes & 5.75 & 0.72 & & $(.78)$ & $.18^{*}$ & -.05 \\
3. Need for Cognition & 3.37 & 0.59 & & & $(.85)$ & -.03 \\
4. Intolerance of Uncertainty & 3.39 & 0.75 & & & & $(.93)$ \\
\hline
\end{tabular}

Note. Due to missing cases, sample size ranged from 138 to 170. Cronbach's Alpha coefficients are presented in the diagonal in parentheses. ${ }^{\dagger} p=.053{ }^{*} p<.05^{* *} p<.01{ }^{* * *} p<.001$.

\section{GENERAL DISCUSSION}

The aim of the present research was to test the structure of scientific values within the framework of Schwartz's (1992) Value Theory. To serve this purpose, nine scientific values were identified referring to the relevant literature, and items were developed to assess their relative importance and the value types originally proposed in SVT. Findings supported the hypothesis that scientific values will be located between Self-Direction and Universalism values. Scientific value items displayed a continuum in creativity, $\mathrm{cu}$ riosity, skepticism, open-mindedness, rationality, objectivity, communality, integrity, and consistency. This continuum started with creativity and curiosity values alongside the two Self-Direction values, which measured the importance of freedom and independence. Together, these compose the original Self-Direction value type content. Skepticism was located between freedom and independence value items, being the first original scientific value item as an anchor to the Self-Direction domain. The remaining scientific value items extended towards the Universalism domain, the integrity value item being the anchor in the end.

The value concept consistency diverged from this continuum towards the Conservation quadrant in the value circle and was close to the Security value type item measuring national security. Since the wording of the consistency item emphasized a lack of contradiction among one's thoughts, its location is entirely unexpected. Ros et al. (1999) demonstrated that teachers who had work experience conceived the work in relation to 
value priorities different than the prospective teachers (i.e., the students). Similarly, students in this study's sample who lacked experience in scientific work might have stuck to their typical representations of consistency as having no discrepancy among internal characteristics and behaviors. Since having such inconsistency would make social reality unpredictable, it could threaten safety, harmony, and stability in relationships, which is the definition of Security values. Therefore, it is believed that this unexpected finding might have stemmed from the experience-related characteristics of the student sample. Future research comparing scientists and students in terms of their value systems is necessary to test this explanation. The findings of the value-type level analysis were even more precise because item-level idiosyncrasies were averaged within the value type scores. In this case, the scientific value type was exactly located between the Self-Direction and Universalism value types. Together, these analyses provided the initial support for the hypothesized structure of scientific values in Schwartz's (1992) value circle.

Scientific value items that were developed initially referred to thought processes. In the refined version of SVT (Schwartz et al., 2012), the Self-Direction value type was partitioned into two subtypes, which are Self-Direction/Thought and Self-Direction/Action facets, the former being adjacent to the Universalism domain. The findings seem to suggest that scientific values are mostly closer to the Thought facet. This inference is in line with the conclusion that adults are more likely to use the word think when they deal with factual beliefs, which comprise the essence of scientific inquiry (Heiphetz et al., 2018). However, since the measurement of the present study was based on the older version of SVT, this implication requires further research in which the scientific value items are generated in the form of the new PVQ measure explicitly developed in line with the refined version of the theory.

The construct validity of the scientific value type was investigated not only through the structural relationships within the value circle but also through the pattern of correlations between the scientific values and the other value types. Borrowing from the circular nature of values, SVT postulates a sinusoidal relationship between a given value type and the other value types. In line with this postulate, support was obtained for the prediction of the study that due to their location between Self-Direction and Universalism values, scientific values would exhibit the highest positive correlations with these value types and the highest negative correlation with their polar opposites, namely the Tradition and Power value types, suggesting convergent validity. The remaining corre- 
lations displayed a gradual decrement/increment when the location of the value type was farther away from the most relevant value types. Moreover, zero correlations were obtained with Benevolence values in Study 2, and with Stimulation in both studies, which indicated divergent validity.

Scientific values had negative correlations with Achievement and Power values. This indicates that scientific values do not represent an inclination toward establishing dominance through control over people and resources. Nor do they seem to express a concern for being successful as it is socially defined. Thus, scientific values become empirically determined through these goal-based distinctions from other value types. Based on the results, it is possible to argue that scientific values specifically guide how the process of scientific thinking should be and how the products of this process must be obtained, and then used (Allchin, 1999; English et al., 2018; Longino, 1983).

In study 2 , the convergent validity of the scientific value type was further supported by its relationship with scientific attitudes, intolerance of uncertainty, and the need for cognition constructs, the last one displaying the most vital relationship. Although it was in line with the prediction, there was a marginally significant relationship between the scientific values and attitudes towards science. It is possible that the semantic differential scale did not sufficiently serve to reveal a stronger association. Future research which takes into account the cognitive component along with the affective component of scientific attitudes might reveal better results. In addition, the weakness of the associations might imply potential moderators involved in the value-outcome variable relationships. Given that data were collected in a student sample, the major of the students might be a candidate moderator. Since the data in the sample of this study came from Faculty of Education students enrolled in two different majors, meaningful comparisons were not possible. Future research with examples from different majors would have utility in testing such potential moderation.

All in all, data from two studies provided initial support for research formulations of the structural quality of the scientific values. As a theoretical note, the present research did not attempt to propose a modification in the original theory. This objective was recently achieved by Schwartz and his colleagues (2012) through maintaining the original motivational postulates of SVT to refine it further. Instead, the aim was to provide evidence that different context-specific values can have a logically tenable and empirically 
verifiable place in the value circle, paying respect to its theoretical qualities; thus, it is possible to translate such groupings into SVT terms. It is believed that such a strategy might prove utility in future research in generating specific hypotheses by referring to the motivational qualities of these values and value groupings which were not previously represented in the original model.

There are certain limitations of the present research which require elaboration. Firstly, in both studies, convenience sampling was employed. However, in Study 1, the sample contained university students from numerous universities located in various cities in Turkey. In Study 2, the majority of the students were women, and men were disproportionately under-represented. In addition, both samples of the study being formed through voluntary participation might have resulted in a self-selection bias, and consequently, the findings might not represent the pattern of associations in the population. These sample characteristics limit the generalizability of the present findings.

Secondly, although the reliability of the scientific values scale was acceptable in both studies, the reliability coefficients of the other value scales were mainly below the conventional level. Unfortunately, the authors are not aware of any paper in the literature concerned with the reliability problems in value measurement with PVQ40. Thus, this problem might have resulted from the characteristics of the sample in the present study. Nevertheless, the other value type scores with low-reliability coefficients were used so that the sinusoidal pattern of correlations as dictated by the circular structure of values in SVT could be tested, and the pattern was replicated in two studies. Thus, for purposes of completeness, the subscales with low reliability were maintained. Although the predicted sinusoidal pattern supported by the data is an indication of validity, despite the low reliabilities, the reader is cautioned that this limitation mandates further testing of the hypothesis using measurement tools with acceptable reliability coefficients.

Thirdly, the data were collected in Turkish samples. In cross-cultural values research, Turkish culture was demonstrated to be located in the midst of Muslim Middle East and the Eastern European cultures (Schwartz, 1994, 1997) although diverging from the Middle Eastern neighbors in showing higher egalitarianism and autonomy, and lower hierarchy and embeddedness in nation-level value priorities (Schwartz, 2014), thus culturally farther away from Western, English-speaking cultures. The scientific value structure and the pattern of correlations with other outcome variables might be different in 
other cultures where independence of thought and action at the individual level and mastery at the cultural level might deeply characterize those cultures. Therefore, future cross-cultural research is needed to further replicate the structure of scientific values and their relationship with other individual differences constructs.

Finally, the convergent validity of the scientific value type was assessed by utilizing a limited number of attitudinal and dispositional variables. Although the pattern of associations was in line with expectations, there is a need to extend the variety of such variables as potential correlates of scientific values. Since the scale of values in scientific work was developed by English et al. (2018) while the data collection for the present study was underway, and thus no Turkish adaptation was available for it, it was not possible to test the convergent validity of our scale vis-à-vis their multidimensional scale, with items having relatively specific wordings targeting the scientist population. This kind of direct convergent validity study would prove the utility of both approaches for the measurement of scientific values. In addition, as demonstrated in previous research, value types have theoretically derived systematic relations with personality dimensions (Bilsky \& Schwartz, 1994; Furnham, 1984; Roccas, Sagiv, Schwartz, \& Knafo, 2002). Therefore, future research can investigate the relationship with scientific values and personality constructs as an attempt to extend the findings of the present study.

To conclude, to the best of our knowledge, the present research was the first attempt to integrate scientific values into the structure of values as proposed by SVT. It is believed that the initial findings reported in the present paper are promising in demonstrating that such integration is both theoretically tenable and empirically verifiable. The items which were developed to measure scientific values also have acceptable psychometric properties to be used as a measurement tool in both scientist and non-scientist populations in future research. 
Peer-review: Externally peer-reviewed.

Author Contributions: Conception/Design of Study- K.D., E.G.; Data Acquisition- K.D., E.G.; Data Analysis/ Interpretation- K.D., E.G.; Drafting Manuscript- K.D., E.G.; Critical Revision of Manuscript- K.D., E.G.; Final Approval and Accountability- K.D.

Conflict of Interest: The authors have no conflict of interest to declare.

Grant Support: The authors declared that this study has received no financial support.

Hakem Değerlendirmesi: Dış bağımsız.

Yazar Katkıları: Çalışma Konsepti/Tasarım- K.D., E.G.; Veri Toplama- K.D., E.G.; Veri Analizi/Yorumlama- K.D., E.G.; Yazı Taslağı- K.D., E.G.; İçeriğin Eleştirel İncelemesi- K.D., E.G.; Son Onay ve Sorumluluk- K.D.

Çıkar Çatışması: Yazarlar çıkar çatışması bildirmemiştir.

Finansal Destek: Yazarlar bu çalışma için finansal destek almadığını beyan etmiştir.

\section{References/Kaynakça}

Algina, J., \& Olejnik, S. (2003). Sample size tables for correlation analysis with applications in partial correlation and multiple regression analysis. Multivariate Behavioral Research, 38(3), 309-323. doi: 10.1207/S15327906MBR3803_02

Allchin, D. (1999). Values in science: An educational perspective. Science \& Education, 8(1), 1-12. doi: 10.1023/A:1008600230536

Anderson, M. S., Ronning, E. A., Vries, R. D., \& Martinson, B. C. (2010). Extending the Mertonian norms: Scientists' subscription to norms of research. The Journal of Higher Education, 81(3), 366393. doi: $10.1080 / 00221546.2010 .11779057$

Arieli, S., Sagiv, L., \& Roccas, S. (2019). Values at work: The impact of personal values in organisations. Applied Psychology: An International Review. Advance online publication. doi: 10.1111/apps. 12181

Bardi, A., Buchanan, K. E., Goodwin, R., Slabu, L., \& Robinson, M. (2014). Value stability and change during self-chosen life transitions: Self-selection versus socialization effects. Journal of Personality and Social Psychology, 106(1), 131-147. doi: 10.1037/a0034818

Bardi, A., \& Schwartz, S. H. (2003). Values and behavior: Strength and structure of relations. Personality and Social Psychology Bulletin, 29(10), 1207-1220. doi: 10.1177/0146167203254602

Berenbaum, H., Bredemeier, K., \& Thompson, R. J. (2008). Intolerance of uncertainty: Exploring its dimensionality and associations with need for cognitive closure, psychopathology, and personality. Journal of Anxiety Disorders, 22(1), 117-125. doi: 10.1016/j.janxdis.2007.01.004

Bilsky, W., \& Schwartz, S. H. (1994). Values and personality. European Journal of Personality, 8(3), 163-181. doi: 10.1002/per.2410080303

Buhr, K., \& Dugas, M. J. (2002). The intolerance of uncertainty scale: Psychometric properties of the English version. Behaviour Research and Therapy, 40(8), 931-945. doi: 10.1016/S00057967(01)00092-4

Buhr, K., \& Dugas, M. J. (2006). Investigating the construct validity of intolerance of uncertainty and its unique relationship with worry. Journal of Anxiety Disorders, 20(2), 222-236. doi: 10.1016/j. janxdis.2004.12.004

Cacioppo, J. T., \& Petty, R. E. (1982). The need for cognition. Journal of Personality and Social Psychology, 42(1), 116. doi: 10.1037/0022-3514.42.1.116

Cacioppo, J. T., Petty, R. E., \& Feng Kao, C. (1984). The efficient assessment of need for cognition. Journal of Personality Assessment, 48(3), 306-307. doi: 10.1207/s15327752jpa4803_13 
Ciarrochi, J., \& Heaven, P. C. (2012). Religious values and the development of trait hope and self-esteem in adolescents. Journal for the Scientific Study of Religion, 51(4), 676-688. doi: 10.1111/j.14685906.2012.01675.x

Cohen, J. (1988). Statistical power analysis for the behavioral sciences (2nd ed). Hillsdale, NJ: Lawrence Erlbaum.

Cohen, A. R., Stotland, E., \& Wolfe, D. M. (1955). An experimental investigation of need for cognition. Journal of Abnormal and Social Psychology, 51(2), 291- 294. doi: 10.1037/h0042761

Corrigan, D. (2015). Values and learning science. In R.F. Gunstone (Eds.), Encyclopaedia of science education (pp. 1091-1093). Dordrecht: Springer. doi: 10.1007/978-94-007-2150-0

Corrigan, D., \& Smith, K. (2015). The role of values in teaching and learning science. In J. M. Deppeler, T. Loreman, R. Smith, \& L. Florian (Eds.) Inclusive pedagogy across the curriculum (pp. 99-117). Bingley: Emerald Group Publishing Limited.

Daniel, E., Schiefer, D., \& Knafo, A. (2012). One and not the same: The consistency of values across contexts among majority and minority members in Israel and Germany. Journal of Cross-Cultural Psychology, 43(7), 1167-1184. doi: 10.1177/0022022111430257

Daniel, E., Schiefer, D., Möllering, A., Benish-Weisman, M., Boehnke, K., \& Knafo, A. (2012). Value differentiation in adolescence: The role of age and cultural complexity. Child Development, 83(1), 322-336. doi: 10.1111/j.1467-8624.2011.01694.x

Demirutku, K., \& Sümer, N. (2010). Temel değerlerin ölçümü: Portre değerler anketi'nin Türkçe uyarlaması [The measurement of basic values: Turkish adaptation of portrait values questionnaire]. Türk Psikoloji Yazıları, 13(25), 17-25.

Dubey, R., Griffiths, T., \& Lombrozo, T. (2019). If it's important, then I am curious: A value intervention to induce curiosity. In A. K. Goel, C. M. Seifert, \& C. Freksa (Eds.), Proceedings of the 41 st Annual Conference of the Cognitive Science Society (pp. 282-288). Montreal, Canada: Cognitive Science Society.

Dugas, M. J., Gosselin, P., \& Ladouceur, R. (2001). Intolerance of uncertainty and worry: Investigating specificity in a nonclinical sample. Cognitive Therapy and Research, 25(5), 551-558. doi: 10.1023/A:1005553414688

English, T., Antes, A. L., Baldwin, K. A., \& DuBois, J. M. (2018). Development and preliminary validation of a new measure of values in scientific work. Science and Engineering Ethics, 24(2), 393-418. doi: 10.1007/s11948-017-9896-0

Farber, B. (1957). An index of marital integration. Sociometry, 20(2), 117-134. doi: 10.2307/2785637

Feather, N. T. (1975). Values in education and society. New York: Free Press.

Furnham, A. F. (1984). Personality and values. Personality and Individual Differences, 5(4), 483-485. doi: 10.1016/0191-8869(84)90018-7

Gardner, R. C., Reynolds, A. G., \& Beinarovics, V. (1969). Personal values and the meaningfulness of value-related words. Psychological Reports, 24(3), 939-942. doi: 10.2466/pr0.1969.24.3.939

Gold, J. A., \& Robbins, M. A. (1979). Attitudes and values: A further test of the semantic memory model. Journal of Social Psychology, 108(1), 75-81. doi: 10.1080/00224545.1979.9711963

Gold, J. A., \& Russ, R. C. (1977). A semantic memory approach to the conceptualization of attitudes and values. Journal of Social Psychology, 102(2), 233-240. doi: 10.1080/00224545.1977.9713269

Gouveia, V. V., Vione, K. C., Milfont, T. L., \& Fischer, R. (2015). Patterns of value change during the life span: Some evidence from a functional approach to values. Personality and Social Psychology Bulletin, 41(9), 1276-1290. doi: 10.1177/0146167215594189

Göz, İ. (2003). Yazılı Türkçenin kelime sıklı̆̆ı sözlüğ̈̈ [Word frequency dictionary of written Turkish]. Ankara, Turkey: Türk Dil Kurumu. 
Guttman, L. (1968). A general nonmetric technique for finding the smallest coordinate space for a configuration of points. Psychometrika, 33(4), 469-506. doi: 10.1007/BF02290164

Gülgöz, S., \& Sadowski, C. J. (1995). Düşünme ihtiyacı ölçeğinin Türkçe uyarlaması ve öğrenci başarısı göstergeleri ile korelasyonu [Turkish adaptation of the Need for Cognition Scale and its correlation with academic performance measures]. Türk Psikoloji Dergisi, 10(35), 15-24.

Heiphetz, L., Landers, C. L., \& Van Leeuwen, N. (2018). Does think mean the same thing as believe? Linguistic insights into religious cognition. Psychology of Religion and Spirituality. doi: 10.1016/j. jesp.2018.03.007

Homer, P. M., \& Kahle, L. R. (1988). A structural equation test of the value-attitude-behavior hierarchy. Journal of Personality and Social Psychology, 54(4), 638-646. doi: 10.1037/00223514.54.4.638

Huuskes, L., Ciarrochi, J., \& Heaven, P. C. (2013). The longitudinal relationships between adolescent religious values and personality. Journal of Research in Personality, 47(5), 483-487. doi: 10.1016/j. jrp.2013.04.010

Jöreskog, K. G., \& Sörbom, D. (2006). LISREL 8.80. Chicago: Scientific Software International. Klare, G. R. (1968). The role of word frequency in readability. Elementary English, 45(1), 12-22.

Kluckhohn, C. (1962). Values and value-orientations in the theory of action. In T. Parsons, \& E. A. Shils (Eds.), Toward a general theory of action (pp. 388-433). Cambridge: Harvard University Press

Knafo, A., \& Sagiv, L. (2004). Values and work environment: Mapping 32 occupations. European Journal of Psychology of Education, 19(3), 255-273. doi:10.1007/BF03173223

Leuty, M. E., \& Hansen, J. I. C. (2011). Evidence of construct validity for work values. Journal of Vocational Behavior, 79(2), 379-390. doi: 10.1016/j.jvb.2011.04.008

Liquin, E. G., Metz, S. E., \& Lombrozo, T. (2020). Science demands explanation, religion tolerates mystery. Cognition, 204, 104398. doi: 10.1016/j.cognition.2020.104398

Longino, H. (1983). Beyond "bad science": Skeptical reflections on the value-freedom of scientific inquiry. Science, Technology, \& Human Values, 8(1), 7-17. doi: 10.1177/016224398300800103

Mahoney, M. J. (1979). Psychology of the scientist: An evaluative review. Social Studies of Science, 9(3), 349-375. doi: 10.1177/030631277900900304

Maio, G. R., Hahn, U., Frost, J. M., \& Cheung, W. Y. (2009). Applying the value of equality unequally: Effects of value instantiations that vary in typicality. Journal of Personality and Social Psychology, 97(4), 598 -614. doi: 10.1037/a0016683

Osgood, C. E., \& Suci, G. J. (1955). Factor analysis of meaning. Journal of Experimental Psychology, 50(5), 325-338. doi: 10.1037/h0043965

Paivio, A., Yuille, J. C., \& Madigan, S. A. (1968). Concreteness, imagery, and meaningfulness values for 925 nouns. Journal of Experimental Psychology, 76(1p2), 1-25. doi: 10.1037/h0025327

Pakizeh, A., Gebauer, J. E., \& Maio, G. R. (2007). Basic human values: Inter-value structure in memory. Journal of Experimental Social Psychology, 43(3), 458-465. doi: 10.1016/j. jesp.2006.04.007

Parks-Leduc, L., Feldman, G., \& Bardi, A. (2015). Personality traits and personal values: A metaanalysis. Personality and Social Psychology Review, 19(1), 3-29. doi: 10.1177/1088868314538548

Petty, R. E., \& Cacioppo, J. T. (1986). Communication and persuasion: Central and peripheral routes to attitude change. New York: Springer-Verlag.

Ripley, J. S., Worthington Jr, E. L., Bromley, D., \& Kemper, S. D. (2005). Covenantal and contractual values in marriage: Marital values orientation toward wedlock or self-actualization (Marital VOWS) scale. Personal Relationships, 12(3), 317-336. doi: 10.1111/j.1475-6811.2005.00118.x 
Roccas, S., Sagiv, L., Schwartz, S. H., \& Knafo, A. (2002). The big five personality factors and personal values.Personality and Social Psychology Bulletin, 28(6), 789-801.doi: 10.1177/0146167202289008

Rokeach, M. (1973). The nature of human values. New York: Free Press.

Rokeach, M. (1979). From individual to institutional values: With special reference to the values of science. In M. Rokeach (Ed.), Understanding human values: Individual and societal (pp. 47-70). New York, NY: The Free Press.

Ros, M., Schwartz, S. H., \& Surkiss, S. (1999). Basic individual values, work values, and the meaning of work. Applied Psychology, 48(1), 49-71. doi: 10.1111/j.1464-0597.1999.tb00048.x

Sagie, A., \& Elizur, D. (1996). The structure of personal values: A conical representation of multiple life areas. Journal of Organizational Behavior, 17(S1), 573-586. doi: 10.1002/(SICI)10991379(199612)17:1+<573::AID-JOB824>3.0.CO;2-7

Sarı, S., \& Dağ, İ. (2009). Belirsizliğe tahammülsüzlük ölçeği, endişe ile ilgili olumlu inançlar ölçeği ve endişenin sonuçları ölçeğinin Türkçe'ye uyarlanması, geçerliliği ve güvenilirliği [Turkish adaptation, validity, and reliability of the intolerance of uncertainty scale, positive beliefs about worry scale, and consequences of worrying scale.], Anadolu Psikiyatri Dergisi, 10, 261-270.

Saroglou, V., Delpierre, V., \& Dernelle, R. (2004). Values and religiosity: A meta-analysis of studies using Schwartz's model. Personality and individual differences, 37(4), 721-734. doi: 10.1016/j. paid.2003.10.005

Schwartz, S. H. (1992). Universals in the content and structure of values: Theoretical advances and empirical tests in 20 countries. In M. P. Zanna (Ed.), Advances in experimental social psychology, (Vol. 25, pp. 1-65). New York: Academic Press. doi: 10.1016/S0065-2601(08)60281-6

Schwartz, S. H. (1994). Beyond individualism and collectivism: New cultural dimensions of values. In U. Kim, H. C. Triandis, Ç. Kağıtçıbaşı, S. Choi, and G. Yoon (Eds.), Individualism and collectivism: Theory, method, and applications (pp. 85-119). Thousand Oaks, CA: Sage Publications.

Schwartz, S. H. (1996). Value priorities and behavior: Applying a theory of integrated value systems. In C. Seligman, J. M. Olson, \& M. P. Zanna (Eds.), The psychology of values: The Ontario symposium, (Vol. 8, pp. 1-24). Hillsdale, NJ: Lawrence Erlbaum Associates.

Schwartz, S. H. (1997). Values and culture. In D. Munro, J. F. Schumaker \& S. C. Carr (Eds.), Motivation and culture (pp. 69-84). New York: Routledge.

Schwartz, S. H. (2003). A proposal for measuring value orientations across nations. In Questionnaire Development Package of the European Social Survey (pp. 259-319). Retrieved from http://www. europeansocialsurvey .org/index.php?optioncom_docman\&taskdoc_view\&gid126\& Itemid80

Schwartz, S. H. (2007). Universalism values and the inclusiveness of our moral universe. Journal of Cross-Cultural Psychology, 38(6), 711-728. doi: 10.1177/0022022107308992

Schwartz, S. H. (2014). National culture as value orientations: Consequences of value differences and cultural distance. In V. A. Ginsburgh \& D. Throsby (Eds.), Handbook of the economics of art and culture (Vol. 2, pp. 547-586). San Diego, CA: Elsevier.

Schwartz, S. H. (2016). Coding and analyzing PVQ-RR data (instructions for the revised Portrait Values Questionnaire). Retrieved from https://www.researchgate.net/publication/308166496_Coding and_analyzing_PVQ-RR_data_instructions_for_the_revised_Portrait_Values_Questionnaire

Schwartz, S. H., Cieciuch, J., Vecchione, M., Davidov, E., Fischer, R., Beierlein, C., ... \& Konty, M. (2012). Refining the theory of basic individual values. Journal of Personality and Social Psychology, 103(4), 663-688. doi: 10.1037/a0029393

Schwartz, S. H., Cieciuch, J., Vecchione, M., Torres, C., Dirilen-Gumus, O., \& Butenko, T. (2017). Value tradeoffs propel and inhibit behavior: Validating the 19 refined values in four countries. European Journal of Social Psychology, 47(3), 241-258. doi: 10.1002/ejsp.2228 
Schwartz, S. H., Sagiv, L., \& Boehnke, K. (2000). Worries and values. Journal of Personality, 68(2), 309-346. doi: 10.1111/1467-6494.00099

Seligman, C., \& Katz, A. N. (1996). The dynamics of value systems. In C. Seligman, J. M. Olson, \& M. P. Zanna (Eds.), The psychology of values: The Ontario symposium, (Vol. 8, pp. 53-75). Hillsdale, NJ: Lawrence Erlbaum Associates.

Sheldon, K. M. (2005). Positive value change during college: Normative trends and individual differences. Journal of Research in Personality, 39(2), 209-223. doi: 10.1016/j.jrp.2004.02.002

Silverman, B. I., Bishop, G. F., \& Jaffe, J. (1976). Psychology of the scientist: XXXV. Terminal and instrumental values of American graduate students in psychology. Psychological Reports, 39(3 suppl), 1099-1108. doi: 10.2466/pr0.1976.39.3f.1099

Tagiuri, R. (1965). Value orientations and the relationship of managers and scientists. Administrative Science Quarterly, 10(1), 39-51. doi: 10.2307/2391648

Toyokawa, N., \& Toyokawa, T. (2013). The construct invariance of family values in Asian and Hispanic immigrant adolescents: An exploratory study. Asian American Journal of Psychology, 4(2), 116125. doi: $10.1037 / \mathrm{a} 0029170$

Verplanken, B., \& Holland, R. W. (2002). Motivated decision making: Effects of activation and selfcentrality of values on choices and behavior. Journal of Personality and Social Psychology, 82 (3), 434-447. doi: 10.1037/0022-3514.82.3.434

Wakefield, J. R., Kalinauskaite, M., \& Hopkins, N. (2016). The nation and the family: The impact of national identification and perceived importance of family values on homophobic attitudes in Lithuania and Scotland. Sex Roles, 75(9-10), 448-458. doi: 10.1007/s11199-016-0641-y

Webster, D. M., \& Kruglanski, A. W. (1994). Individual differences in need for cognitive closure. Journal of Personality and Social Psychology, 67(6), 1049-1062. doi: 10.1037/0022-3514.67.6.1049

Williams, R. M. (1979). Change and stability in values and value systems: A sociological perspective. In M. Rokeach (Ed.), Understanding human values: Individual and societal (pp. 15-46). New York: The Free Press.

Yalçındağ, B. (2015). Searching for the content and scope of morality with a framework of moral foundations theory (Unpublished Doctoral Dissertation). Middle East Technical University, Ankara.

Yalçındağ, B., Özkan, T., \& Çoymak, A. (2018, July). The effect of moral values on predicting attitudes towards different social groups. Poster presented at $41^{\text {st }}$ Annual Meeting of International Society for Political Psychology (ISPP), San Antonio, USA. 
